\title{
Ecology and natural history of Akodon lindberghi (Rodentia, Sigmodontinae) in southeastern Brazil
}

\author{
Diego Queirolo \& Marco A. M. Granzinolli
}

Departamento de Ecologia, Instituto de Biociências, Universidade de São Paulo, Rua do Matão 321, travessa 14, Cidade Universitária, 05508-900 São Paulo, SP, Brazil. (diqueirolo@yahoo.com.br)

\begin{abstract}
We studied the ecology and natural history of the globally threatened and poorly known Akodon lindberghi Hershkovitz, 1990 in Parque Nacional da Serra da Canastra (PNSC) and Juiz de Fora (JF), southeastern Brazil. From November 1998 to September 2001 a total of 131 individuals were captured in wire-cage live-traps and 52 by pitfalls traps. They were all marked and released at the site. The largest abundances were registered during the dry season, and most of the captures occurred in open habitats. The mean body mass of the two populations was significantly different ( $18.1 \mathrm{~g}$ at PNSC versus $13.1 \mathrm{~g}$ at JF; $\mathrm{H}=46.2678, \mathrm{~g} .1 .=2$, $\mathrm{p}<0.001)$. In PNSC, individuals were reproductively active from August to February, and juveniles were present from May to August. The results suggest that the changes in vegetation structure caused by deforestation and intensive agricultural activities could increase the predation rate, affecting the mean body mass of the population.
\end{abstract}

KEYWORDS. Akodon lindberghi, reproduction, abundance, body mass, population structure.

RESUMO. Ecologia e historia natural de Akodon lindberghi (Rodentia, Sigmodontinae) no sudeste do Brasil. Investigouse a ecologia e a historia natural do globalmente ameaçado e pouco conhecido Akodon lindberghi Hershkovitz, 1990 no Parque Nacional da Serra da Canastra (PNSC) e no município de Juiz de Fora (JF), sudeste do Brasil. Entre novembro de 1998 e setembro de 2001 foram capturados 131 indivíduos utilizando-se armadilhas do tipo gaiola e 52 indivíduos por meio de armadilhas de interceptação e queda. As maiores abundâncias ocorreram durante a estação seca, com a maioria das capturas realizadas em ambientes dominados por gramíneas e arbustos esparsos. A massa corporal média foi significativamente diferente entre as duas populações (18,1 g no PNSC versus $13,1 \mathrm{~g}$ em JF; $\mathrm{H}=46.2678$, g.l. $=2, \mathrm{p}<0.001$ ). No PNSC, os indivíduos mostraram-se reprodutivamente ativos entre agosto e fevereiro, registrando-se a presença de juvenis entre maio e agosto. Os resultados sugerem que a perda na estrutura da vegetação causada por desmatamento e atividades agropecuárias intensivas poderiam incrementar a taxa de predação e afetar a massa corpórea média da população.

PALAVRAS-CHAVE. Akodon lindberghi, reprodução, abundância, massa corporal, estrutura da população.

The genus Akodon Meyen, 1833 is widely distributed in the Neotropics, mainly the Andean habitats of western South America (Reig, 1987; Sмітн \& PATton, 1993). This genus presents some taxonomic problems due to the great morphological similarities among species groups, making karyotypical analyses necessary for the correct identification of most Brazilian species (CHRISTOFF et al., 2000; GonÇALves et al., 2007).

Lindbergh's grass mouse Akodon lindberghi Hershkovitz, 1990 was described recently, and has been recorded from two localities: Parque Nacional de Brasília, in the Brazilian Federal District, type locality (HERSHKOVITZ, 1990), and the municipality of Simão Pereira, in the State of Minas Gerais (GeIse et al., 1996). Furthermore, the number of individuals captured/analyzed in these two areas was small $(n=7$ and $n=8$, respectively). Data regarding morphological characters of the species, its habitat or the interaction with the rodent community are still scarce (HershKovitz, 1990; GeIse et al., 1996), and information about behaviour or reproduction is lacking.

Lindbergh's grass mouse is listed as globally vulnerable (IUCN, 2007), as it has a restricted and patchy distribution, and biological data are still scarce. However, this species is not on the Brazilian endangered species list (DOU, 2003).

In the present paper, we supply information about two new areas of occurrence of Lindbergh's grass mouse, and describe for the first time some of its ecological and natural history aspects, such as abundance, habitat preferences, body mass, reproduction and population structure.

\section{MATERIAL AND METHODS}

The study was conducted at two localities (Fig. 1). Serra da Canastra National Park (PNSC), located in the southwestern portion of the State of Minas Gerais $\left(20^{\circ} 20^{\prime} \mathrm{S}-46^{\circ} 40^{\prime} \mathrm{W}\right)$, with a total area of $200,000 \mathrm{ha}$, protected since 1982 . It is characterized by gently sloping plateaus, ranging from $800 \mathrm{~m}$ to $1,496 \mathrm{~m}$ of elevation, surrounded by steep slopes in the highest part. The climate of the region is $\mathrm{Cwb}$, according to Köppen's system (Trewartha \& Horn, 1980), characterized by a dry and cool season from April to September, with a mean temperature of $17^{\circ} \mathrm{C}$, and a wet and hot season from October to March, with mean temperature of $22^{\circ} \mathrm{C}$. The annual precipitation ranges from 1,300 to $1,700 \mathrm{~mm}$ (about $1,500 \mathrm{~mm}$ registered during the study period), with a peak period from December to February (IBDF/FBCN, 1981). The vegetation physiognomy, in agreement with EITEN (1994), is included in the Cerrado domain, with 
predominance of open habitats, composed mainly of herbaceous species (campo limpo), with permanently flooded areas (campo úmido), scattered and sparsely distributed arboreal species and shrubs (campo sujo and campo cerrado) and areas of high-elevation rocky meadows (campo rupestre). Gallery forests appear along the rivers, covering less than $2 \%$ of the total surface of PNSC (IBDF/FBCN, 1981).

Private areas at Juiz de Fora (JF), including a group of private farmlands totalling approximately 17,537 ha, located in the northern portion of the municipality of Juiz de Fora $\left(21^{\circ} 41^{\prime} \mathrm{S}, 43^{\circ} 27^{\prime} \mathrm{W}\right)$, in the southeastern part of the State of Minas Gerais. The relief is mountainous, with altitudes near $1,000 \mathrm{~m}$ at the highest points and mean elevation around $800 \mathrm{~m}$ (Juiz de Fora, 1996). According to Köppen's system (Trewartha \& Horn, 1980), the climate is Cwa, characterized by a wet season from October to April, with mean temperature of $20.2^{\circ} \mathrm{C}$, and a dry season from May to September, with mean temperature of $16.8^{\circ} \mathrm{C}$. The annual precipitation averages $1,536 \mathrm{~mm}$, with the highest rainfall in January. The native vegetation of the area is a semi-deciduous forest (Veloso \& Góes-Filho, 1982), but several cycles of deforestation destroyed most of it, making way for livestock and agriculture (JUIZ DE FORA, 1996). The landscape is currently a mosaic of larger portions of open areas (pastures and agricultural activities), small and medium size forest fragments located mainly on hill tops and steep areas, and cultivation of exotic species of Eucalyptus spp. (Myrtaceae) and Pinus spp. (Pinaceae) (Juiz de Fora, 1996).

At both localities, we carried out a capture-markrecapture study of small mammals, and the animals were marked with ear-perforations. The term "capture" means the first capture of an animal in each trapping period, regardless of whether or not it had already been marked in another occasion.

In the PNSC, the study was conducted monthly from November 1998 to January 2000, excluding November 1999. We used 135 wire-cage live-traps $(45 \times 20 \times 20 \mathrm{~cm})$, placed $15 \mathrm{~m}$ apart on the ground, and baited with peanut butter, banana, vanilla, maize flour,

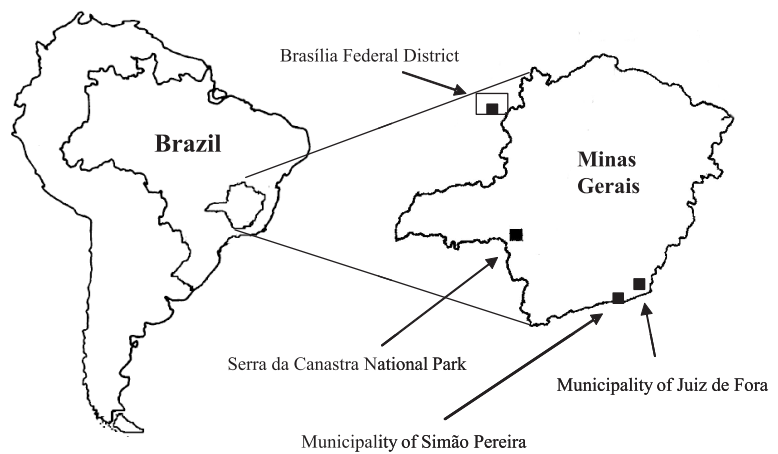

Figure 1. Location of study areas, Serra da Canastra National Park and Juiz de Fora municipality, and the other two previous localities, Brasília Federal District and Simão Pereira municipality, State of Minas Gerais, Brazil. and sardine slices. They were distributed in nine linetransects, three in each of the main habitats of the Park (gallery forest, campo úmido/limpo and campo sujo/cerrado), during three nights per trapping period, amounting to a total of 5,022 traps/night.

In JF, the study was carried out monthly from September 2000 to September 2001, except for November 2000, and we used two kinds of traps: a) wire-cage live-traps $(45 \times 20 \times 20 \mathrm{~cm})$, baited with peanut butter, banana, maize flour, and sardine slices, distributed in eight sets of traps. Each set consisted of 12 wire-cage live-traps, distributed in three parallel lines, spaced $45 \mathrm{~m}$ apart, totalling 96 traps. The distance between traps within lines was $15 \mathrm{~m}$. These traps were placed along open areas (mainly pastures), during three nights per trapping period; b) pitfall traps, distributed in five sets of traps. Each set consisting of 12 buckets (36 liters each), distributed in three lines, totaling 60 traps, placed in the same arrangement and $45 \mathrm{~m}$ apart as the previous traps. The buckets $(44 \mathrm{~cm}$ deep and $39 \mathrm{~cm}$ in diameter) were connected with a 50 $\mathrm{cm}$-high plastic fence (following FrIEND et al., 1989). Pitfalls were inspected on the same days as wire-cage live-traps. The total sampling effort was 3,456 wirecage live-traps /night and 2,160 pitfalls/night.

The total number of captured animals, by locality and type of trap, was used as the abundance index, calculated per trapping period. The individuals captured in each locality were grouped according to the body mass, and the body mass proportions were compared in both populations and among the different capture methods, by using the Kruskal-Wallis nonparametric test, followed by Dunn multiple comparison tests (ZAR, 1999). Statistical analyses were conducted using the statistical package BioEstat 3.0 (Ayres et al., 2003). The collected specimens will be deposited in the mammal collection of the Museu de Zoologia, Universidade de São Paulo and in the Laboratório de Ecologia Trófica, Departamento de Ecologia of the same university.

In addition, for the individuals captured in the PNSC, external analysis of the reproductive characters was used to determine the stage of development and reproductive condition. Reproductively active animals (males with scrotal testes and females with perforated vagina), and reproductively inactive animals (males with abdominal testes and females with unperforated vagina), were determined. Finally, individuals with smaller body mass than the smallest reproductively active male or female were considered juveniles, and those reproductively active were considered adults.

\section{RESULTS}

In the PNSC, 87 individuals were captured (32.9\% females and $67.1 \%$ males). The highest abundances were recorded from April to September, and the lowest in the rainy season (Fig. 2). In JF, 52 individuals were captured in pitfall traps (55.8\% females and $44.2 \%$ males $)$, 
while wire-cage live-traps were responsible for 44 records (52.3\% females and $47.7 \%$ males). The highest abundances were recorded in the dry season, as in the PNSC (Fig. 3).

In the PNSC, the Lindbergh's grass mouse was captured in open habitats with a predominance of herbaceous species and scattered bushes, such as the campo úmido (56.6\%), campo limpo (30.9\%), campo sujo $(8.8 \%)$ and in forest edge $(3.8 \%)$, always near campo limpo habitats. In JF, the captures also occurred in open habitats, with the largest number occurring close to swamps $(53.1 \%)$, also with a predominance of herbaceous species.

Individual body mass varied from 11 to $31 \mathrm{~g}$ in the PNSC, and from 6 to $27 \mathrm{~g}$ in JF. The body mass analysis of the individuals captured in the PNSC and JF shows that there are significant differences among the three approaches (pitfall from JF, wire-cage livetrap from JF and wire-cage live-trap from PNSC) $(\mathrm{H}=$ 46.2678, g.1. $=2, \mathrm{p}<0.001)$. The Dunn multiple comparisons test verified that there is no significant difference among the body mass of the individuals captured using pitfalls and wire-cage live-traps in JF $(z=0.329 ; p>0.50)$. However, a significant difference

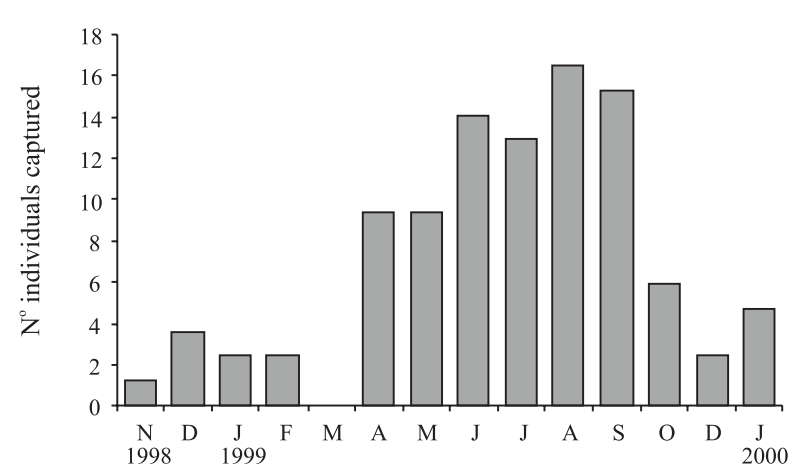

Figure 2. Number of individuals captured between November 1998 and January 2000 of Akodon lindberghi Hershkovitz, 1990 in the Serra da Canastra National Park State of Minas Gerais, Brazil ( $\mathrm{n}=$ $87 ; 5,022$ trap/nights). was noticed among the body mass of the individuals captured in the PNSC when compared to the individuals captured with wire-cage live-traps $(\mathrm{z}=5.219 ; \mathrm{p}<0.001)$ and pitfall traps $(\mathrm{z}=5.922 ; \mathrm{p}<0.001)$ in JF. The mean weight of the population in the PNSC was $18.1 \mathrm{~g} \mathrm{(SD}=$ $4.8 \mathrm{~g}$ ), and $13.1 \mathrm{~g}$ in JF ( $\mathrm{SD}=3.4 \mathrm{~g}$ ) (mean of $13.1 \mathrm{~g}$ for both method).

Regarding the individual body mass, PNSC presents a larger proportion of individuals greater than $15 \mathrm{~g}$ (Fig. 4), responsible for $62 \%$ of the captures, while in JF they represent $14.2 \%$ of individuals captured in pitfalls and $25 \%$ of individuals registered in wire-cage live-traps. Moreover, no individuals weighing less than $11 \mathrm{~g}$ were captured in the PNSC (Fig. 4).

In the PNSC, reproductively active individuals were found from August to February, most of them in the rainy season, and from December to February all the captured individuals were in these categories (Fig. 5). Taking into account the body mass of reproductively active individuals in the PNSC, two age classes were considered: juveniles $(<13 \mathrm{~g})$ and adults $(\geq 13 \mathrm{~g})$. The analysis revealed that $11.5 \%$ of the population was juveniles, captured from May to August (Fig. 5).

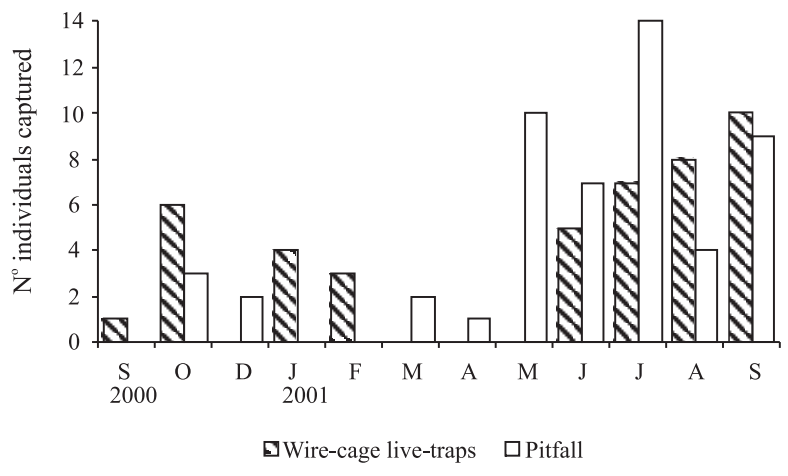

Figure 3. Number of individuals captured between September 2000 and September 2001 of Akodon lindberghi Hershkovitz, 1990 in Juiz de Fora municipality (State of Minas Gerais, Brazil) in wirecage live-traps $(\mathrm{n}=44 ; 3,456$ trap/nights $)$ and pitfalls $(\mathrm{n}=52 ; 2,160$ pitfall/nights).

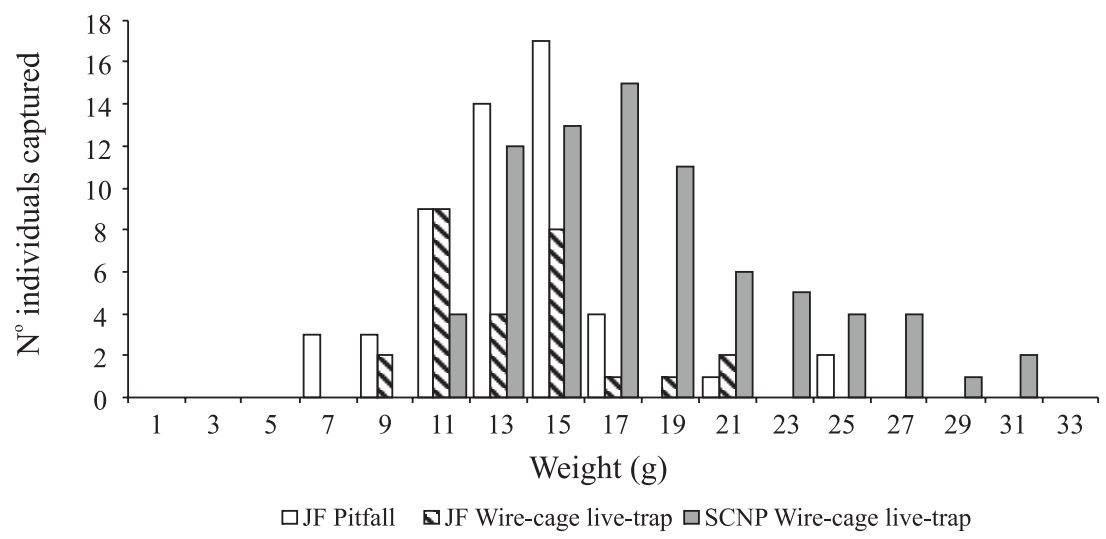

Figure 4. Number of individuals captured of Akodon lindberghi Hershkovitz, 1990 and their body mass in Serra da Canastra National Park (wire-cage live-traps, $\mathrm{n}=78$ ) and Juiz de Fora municipality, State of Minas Gerais, Brazil (pitfalls, $\mathrm{n}=50$, and wire-cage live-traps, $\mathrm{n}=41$ ). Data collected from November 1998 to January 2001 in Serra da Canastra National Park and from September 2000 to September 2001 in Juiz de Fora municipality (JC, Juiz de Fora municipality; SCNP, Serra da Canastra National Park). 


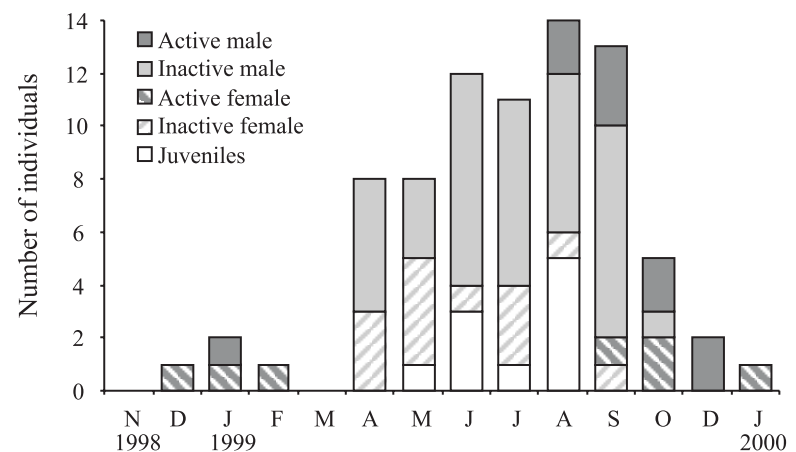

Figure 5. Population structure and reproductive condition of Akodon lindberghi Hershkovitz, 1990 in Serra da Canastra National Park, State of Minas Gerais, Brazil.

\section{DISCUSSION}

TALAMONI \& DiAS (1999) reported that Akodon montensis Thomas, 1913 displayed higher population sizes in semi-deciduous forest, mainly from January through August (mid-rainy season to mid-dry season), when the highest abundances were recorded. On the other hand, FonseCA \& KIERULFF (1989) found a distinct peak in population density of $A$. cursor Winge, 1887 between May and July (dry season), and very few individuals were recorded during the rainy season. Species of the genus were studied in other Neotropical regions (Argentina and Chile), and the seasonal patterns in density found for this species varied among areas, with some reporting patterns similar to those of $A$. lindberghi reported here (Mills et al., 1991; Busch \& KraVetz, 1992; MeSERVE et al., 1999), and others reporting different patterns, with higher density in the summer (FULK, 1975).

Apparently, A. lindberghi has a seasonal breeding period in the rainy season, different from other species found in open habitats, such as Necromys lasiurus Lund, 1840 , which varies according to the region, presenting reproduction year-round with a peak in the rainy season (DieTz, 1983) or in the dry season (Alho \& Pereira, 1985), and Calomys callosus Rengger, 1830, with uniform reproductive activity throughout the year (Aьно \& Pereira, 1985; Vieira, 1997). Species like A. montensis and A. cursor have also been observed to breed yearround, with greater intensity during the rainy season for A. montensis, associated with the seasonal fluctuation in food resources observed in semi-deciduous forest (Cerqueira et al., 1993; TAlamoni \& Dias, 1999).

Reproductive success of small mammals appears to be dependent on environmental conditions, mainly food availability (Alno et al., 1986; AdLER \& BEATTY, 1997). In this case, A. lindberghi presents a breeding season period during the rainy season, but the greatest production of grass seed in Cerrado is during the height of the dry season, when the peak in density occurs (ALHO \& Pereira, 1985; Alno et al., 1986). At least, partially this fact could be explained by the omnivorous habits of the Akodon Meyen, 1833 species, which eat fruits, seeds, insects, and some vegetation (EISENBERG \& REDFORD, 1999). Reproductive activity in tropical savannah rodents is often related to rainfall (HAPPOLD, 1983), nevertheless, reproductive period varies according to habitat (ALHO \&
Pereira, 1985). Dietz (1983) showed that the reproductive activity of the small mammal community in the PNSC occurred year-round, with peaks during the wet season for most species. More studies of the relationship between resource abundance, density and reproductive activity for this species will possibility contribute to a better understanding of its population dynamic.

The largest body mass registered in individuals from PNSC can be related to the fact that this locality is a protected area and, as such, it is in a better condition of conservation, with an increase in habitat complexity and heterogeneity (QUEIROLO \& MotTA-JÚNIOR, 2000) compared to the open habitats in JF area. As a consequence, the individuals in JF could be subject to a larger predation risk, which could be acting strongly on larger individuals, due to habitat modification, reducing the survival time of the heavier adults (Meserve et al., 1993). The habitat modification would be causing a decline in the density of vegetation cover, with a reduction in refuges and a rise in vulnerability. The presence of human activity, such as livestock, would be contributing strongly to this decrease, favouring those individuals of smaller body mass by increasing their probability of taking refuge (Simonetti, 1989; Longland \& Price, 1991; Meserve et al., 1993).

These questions generate hypotheses to be tested in future studies, opening a promising view toward studies of predator-prey mechanisms and their consequences. Current environmental alteration, such as habitat fragmentation and changes in the structure and composition of vegetation, would be causing direct effects in the behaviour, composition and structure of the resident animal communities.

From our results, it is clear that Lindbergh's grass mouse is a species of open and humid habitats, with predominance of herbaceous vegetation, with some scattered scrub species. The kind of habitats in which $A$. lindberghi was captured in the present paper are similar to those found at Parque Nacional de Brasília, where the species was captured for the first time (BORCHERT \& HANSEN, 1983; HershKovitz, 1990), suggesting that this is the most favourable habitat type for this species. Lindbergh's grass mouse is the only tropical Brazilian species of the genus that exclusively inhabits open areas, unlike the others that inhabit almost exclusively forested and shrubby habitats (MAREs et al., 1986; ChristofF et $a l ., 2000)$. Knowledge regarding the biology and ecology of the species of the genus Akodon in Brazil is scarce, with the limited information available originating from studies of small mammal communities (e.g. NITIKMAN \& Mares, 1987; FonseCa \& Robinson, 1990; Cerqueira et al., 1993; Gentile \& Fernandez, 1999; Talamoni \& Dias, 1999).

Finally, this study shows that the distribution of Lindbergh's grass mouse is wider than the limits previously described. It seems that the species occurs in central Brazil, mainly in the States of Minas Gerais, Goiás and the Brazilian Federal District. The occurrence of this species in the PNSC is relevant, since it is a locality between $\mathrm{JF}$ and the two previous records. It is also interesting to note that this species might be extending its original distribution, and colonizing open areas that were once forests, justifying its presence within the Atlantic forest domain (JF and Simão Pereira municipality). 
Acknowledgments. We thank all the people who assisted us during the fieldwork, IBAMA for the authorization to work in the PNSC, and several farmers who allowed us to work in their properties in JF. We would also like to thank the researchers of the Laboratório de Citogenética do Instituto de Biociências da Universidade de São Paulo (IB-USP) and Graziela Dotta for reviewing the manuscript. We thank CAPES and the World Wildlife Fund (WWF Brasil-CSR 123-99) for providing a scholarship and financial support for DQ; and CNPq for the scholarship granted to MAMG. FAPESP (grant 97/6090-7) and WWF Brasil (CSR 123-99) provided financial support to DQ. The Curso de Pós-graduação em Ecologia IB-USP supplied financial support to MAMG and DQ.

\section{REFERENCES}

Adler, G. H. \& Beatty, R. P. 1997. Changing reproductive rates in a Neotropical forest rodent, Proechimys semispinosus. Journal of Animal Ecology 66:472-480.

Alho, C. J. R. \& Pereira, L. A. 1985. Population ecology of a Cerrado rodent community in central Brazil. Revista Brasileira de Biologia 45:597-607.

Alho, C. J. R.; Pereira, L. A. \& Paula, A. C. 1986. Patterns of habitat utilization by small mammal populations in Cerrado biome of central Brazil. Mammalia 50:447-460.

Ayres, M.; Ayres Jr., M.; Ayres, D. L. \& Ayres, A. S. dos 2003. BioEstat 3.0: Aplicações Estatísticas nas Áreas das Ciências Biológicas e Médicas. Belém e Brasília, Sociedade Civil Mamirauá e CNPq. 290p.

Borchert, M. \& Hansen, R. L. 1983. Effects of flooding and wildfire on valley side wet campo rodents in central Brazil. Revista Brasileira de Biologia 43:229-240.

Busch, M. \& Kravetz, F. O. 1992. Competitive interactions among rodents (Akodon azarae, Calomys laucha, Calomys musculinus and Oligoryzomys flavescens) in a two-habitat system. II. Effect of species removal. Mammalia 56:541-554.

Cerqueira, R.; Gentile, R.; Fernandez, F. A. Z. \& D’Andrea, P. S. 1993. A five-year population study of an assemblage of small mammals in southeastern Brazil. Mammalia 57:507-517.

Christoff, A. U.; Fagundes, V.; Sbalqueiro, I. J.; Mattevi, M. S. \& Yonenaga-Yassuda, Y. 2000. Description of a new species of Akodon (Rodentia: Sigmodontinae) from southern Brazil. Journal of Mammalogy 81:838-851.

Dietz, J. M. 1983. Notes on the natural history of some small mammals in central Brazil. Journal of Mammalogy 64:521523.

DOU (DiÁRIO Oficial DA UnIão). 2003. Instrução Normativa $N^{03}$, de 27 de Maio de 2003. Brasília, Diário Oficial da União, 101, seção 1. p.88-97.

Eisenberg, J. F. \& Redford, K. H. 1999. Mammals of the Neotropics. Chicago, The University of Chicago. v.3, 609p.

Eiten, G. 1994. Vegetação do Cerrado. In: Pinto, M. N. ed. Cerrado: Caracterização, Ocupação e Perspectivas. Brasília, Universidade de Brasília. p.17-73.

Fonseca, G. A. B. Da \& KierulfF, M. C. M. 1989. Biology and natural history of Brazilian Atlantic Forest small mammals. Bulletin of the Florida State Museum, Biological Science 34:99-152.

Fonseca, G. A. B. DA \& Robinson, J. G. 1990. Forest size and structure: competitive and predatory effects on small mammal communities. Biological Conservation 53:265-294.

Friend, G. R.; Smith, G. T.; Mitchell, D. S. \& Dickmam, C. R. 1989. Influences of pitfall and drift fence design on capture rates of small vertebrates in semi-arid habitats of Western Australia. Australian Wildlife Research 16:1-10.

FuLK, G. W. 1975. Population ecology of rodents in the semiarid shrublands of Chile. Occasional Papers, Museum of Texas Tech University 33:1-40.

Geise, L.; Cerqueira, R. \& Seuánez, H. N. 1996. Karyological characterization of a new population of Akodon lindeberghi in Minas Gerais State (Brazil). Caryologia 49:59-63.

Gentile, R. \& Fernandez, F. A. S. 1999. Influence of habitat structure on a streamside small mammal community in a Brazilian rural area. Mammalia 63:29-40.
Gonçalves, P. R.; Myers, P.; Vilela, J. F. \& Oliveira, J. A. 2007. Systematic of species of the genus Akodon (Rodentia: Sigmodontinae) in Southeastern Brazil and implications for the biogeography of the Campos de Altitude. Miscellaneous Publications, Museum of Zoology, University of Michigan 197:1-24.

Happold, D. C. D. 1983. Rodents and Lagomorphs. In: BourLière, F. ed. Tropical Savannas. Wembley, CSRIO. p.363-400.

Hershkovitz, P. 1990. Mice of the Akodon boliviensis size class (Sigmodontinae: Cricetidae) with description of two new species from Brazil. Fieldiana: Zoology 57:1-35.

IBDF/FBCN (Instituto Brasileiro de Desenvolvimento Florestal, Fundação Brasileira para a Conservação da Natureza). 1981. Plano de Manejo: Parque Nacional da Serra da Canastra. Brasília, Instituto Brasileiro de Desenvolvimento Florestal, Fundação Brasileira para a Conservação da Natureza. $96 \mathrm{p}$.

IUCN (International Union for Conservation of Nature). 2007. Red List of Threatened Species. Available at: $<$ www.iucnredlist.org $>$. Accessed on: 11.08.2008.

Juiz DE Fora. 1996. Plano Diretor de Juiz de Fora. Juiz de Fora, Prefeitura de Juiz de Fora, Instituto de Pesquisa e Planejamento. $215 \mathrm{p}$.

Longland, W. S. \& Price, M. V. 1991. Direct observations of owls and heteromyid rodents: can predation risk explain microhabitat use? Ecology 72:2261-2273.

Mares, M. A.; Ernest, K. A. \& Gettinger, D. D. 1986. Small mammal community structure and composition in the Cerrado Province of central Brazil. Journal of Tropical Ecology 2:289-300.

Meserve, P. L.; Gutierrez, J. R. \& Jaksic, F. M. 1993. Effects of vertebrate predation on a caviomorph rodent, the degu (Octodon degus), in a semiarid thorn scrub community in Chile. Oecologia 94:153-158.

Meserve, P. L.; Martínez, D. R.; Rau, J. R.; Murúa, R.; Lang, B. K. \& Muñoz-Pedreros, A. 1999. Comparative demography and diversity of small mammals in precordilleran temperate rainforests of southern Chile. Journal of Mammalogy 80:880-890.

Mills, J. N.; Ellis, B. A.; McKee, K. T.; Maiztegui, J. I. \& Childs, J. E. 1991. Habitat associations and relative densities of rodent populations in cultivated areas of central Argentina. Journal of Mammalogy 72:470-479.

Nitikman, L. Z. \& Mares, M. A. 1987. Ecology of small mammals in a gallery forest of central Brazil. Annals of the Carnegie Museum 56:75-95.

Queirolo, D. \& Motta-Junior, J. C. 2000. Possível influência das mudanças da paisagem no Parque Nacional da Serra da Canastra - MG na dieta do Lobo-Guará, (Chrysocyon brachyurus). In: Congresso Brasileiro de Unidades de Conservação, $2^{\circ}$, Campo Grande. Anais... v.2. p.706-714.

ReIG, O. A. 1987. An assessment of the systematics and evolution of the Akodontini, with the description of new fossil species of Akodon (Cricetidae: Sigmodontinae). Fieldiana: Zoolology 39:347-399.

Simonetti, J. A. 1989. Microhabitat use by small mammals in central Chile. Oikos 56:309-318.

Smith, M. F. \& Patton, J. L. 1993. The diversification of South American murid rodents: evidence from mitochondrial DNA sequence data for the akodontine tribe. Biological Journal of the Linnean Society 50:149-177.

Talamoni, S. A. \& Dias, M. M. 1999. Population and community ecology of small mammals in southeastern Brazil. Mammalia 63:167-181.

Tremartha, G. T. \& Horn, L. H. 1980. An introduction to climate. $5^{\text {th }}$ ed. New York, McGraw-Hill. 416p.

Veloso, H. P. \& Góes-Filho, L. 1982. Fitogeografia Brasileira: Classificação Fisionômica-Ecológica da Vegetação Neotropical. Salvador, Ministério das Minas e Energia. 85p. VIEIRA, M. V. 1997. Dynamics of a rodent assemblage in Cerrado of southeast Brazil. Revista Brasileira de Biologia 57:99107.

Zar, J. H. 1999. Biostatistical Analysis. New Jersey, Prentice Hall. $718 \mathrm{p}$.

Recebido em fevereiro de 2007. Aceito em setembro de 2008. ISSN 0073-4721

Artigo disponível em: www.scielo.br/isz

Iheringia, Sér. Zool., Porto Alegre, 99(2):189-193, 30 de junho de 2009 